\title{
POLD3 wt Allele
}

National Cancer Institute

\section{Source}

National Cancer Institute. POLD3 wt Allele. NCI Thesaurus. Code C106228.

Human POLD3 wild-type allele is located in the vicinity of 11 q14 and is approximately 175 $\mathrm{kb}$ in length. This allele, which encodes DNA polymerase delta subunit 3 protein, is involved in the positive regulation of DNA replication. Somatic mutation of the gene may be associated with renal cell carcinoma. 